
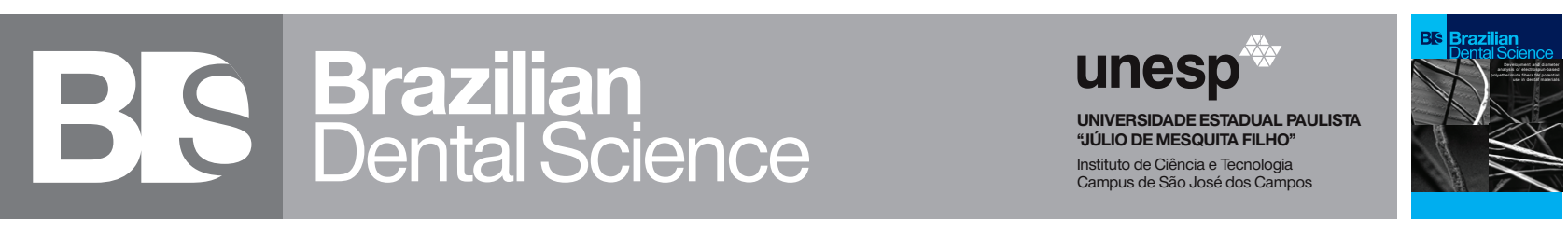

\title{
Cephalometric comparison of dentofacial parameters between Yemeni and Caucasian adults
}

\author{
Comparação cefalométrica de parâmetros dentofaciais entre adultos iemenitas e caucasianos
}

Amal A. AL-YOUSEFI ${ }^{1}$, Khaled AL- HADDAD ${ }^{2}$, Ammar DAER ${ }^{1}$, Mohammed A. AL-LABANI ${ }^{1}$

1 - Division of Orthodontics, Department of Orthodontics, Pedodontics and Prevention, Faculty of Dentistry, Sana'a University, Sana'a, Yemen.

2 - Division of Pedodontics, Department of Orthodontics, Pedodontics and Prevention, Faculty of Dentistry, Sana'a University, Sana'a, Yemen.

\section{ABSTRACT}

Objective: The purposes of our research were to establish cephalometric standards for Yemeni adults and to compare them with those of the Caucasians. Material and Methods: 100 Yemeni students (fifty males, mean age of $23.6 \pm 2.1$ years, and fifty female, mean age of $21.5 \pm 3.1$ years) with normal occlusions and well-balanced faces were involved in the study. Inclusion criteria were a class I occlusion with minor or no crowding, the whole teeth is present except third molars and no previous orthodontic, orthopedic or maxillofacial surgery treatment. Five angular and eighteen linear measurements were used for the skeletal, dental and soft tissue analysis. All participant's Lateral cephalometric radiographs were evaluated. The average values and standard deviations for all the angles and linear measurements were determined. The differences for each measurement between the Yemeni and Caucasian participants were calculated using unpaired ttests. Results: Yemeni subjects had a more retrognathic mandibular positions $(\mathrm{P}<0.05)$, protrusive mandibular incisors $(\mathrm{P}<0.01)$, more protruded lip positions ( $\mathrm{P}$ $<0.01)$, deeper mentolabial sulci $(\mathrm{P}<0.01)$ and a steeper mandibular planes $(\mathrm{P}<0.001)$ compared to the Caucasians. Yemeni females had a larger lower face height than Caucasian females $(\mathrm{P}<0.001)$. Conclusions The study provides specific standards for Yemeni adults and shows that the Yemenis had different skeletal and dentoalveolar cephalometric standards in comparison with Caucasians.

\section{KEYWORDS}

Cephalometric comparison; Skeletal and dental features; Yemeni norms.

\section{RESUMO}

Objetivo: O objetivo de nossa pesquisa foi estabelecer padrões cefalométricos para adultos iemenitas e compará-los com os caucasianos. Material e Métodos: Cem estudantes iemenitas (cinquenta homens, idade média de 23,6 \pm 2,1 anos, e cinquenta mulheres, idade média de 21,5 $\pm 3,1$ anos) com oclusões normais e faces bem equilibradas foram envolvidos no estudo. Os critérios de inclusão foram: oclusão de classe I com pouco ou nenhum apinhamento, todos os dentes presentes, exceto terceiros molares e sem histórico de tratamento ortodôntico, ortopédico ou cirurgia maxilofacial prévio. Cinco medidas angulares e dezoito lineares foram utilizadas para a análise esquelética, dentária e de tecidos moles. Todas as radiografias cefalométricas laterais dos participantes foram avaliadas. Foram determinados os valores médios e desvios padrão para todos os ângulos e medidas lineares. As diferenças para cada medição entre os participantes iemenitas e caucasianos foram calculadas usando testes t não pareados. Resultados: Os indivíduos iemenitas tinham posições mandibulares mais retrognáticas $(\mathrm{P}<0,05)$, incisivos inferiores protrusivos $(\mathrm{P}<0,01)$, posições dos lábios mais protuberantes ( $\mathrm{P}<0,01)$, sulcos mentolabiais mais profundos $(\mathrm{P}<0,01)$ e planos mandibulares mais inclinados ( $\mathrm{P}<0,001)$ em comparação com os caucasianos. As mulheres iemenitas tinham uma altura facial inferior maior do que as mulheres brancas ( $\mathrm{P}<0,001)$. Conclusão: O estudo fornece padrões específicos para adultos iemenitas e mostra que os iemenitas apresentaram padrões cefalométricos esqueléticos e dentoalveolares diferentes em comparação com os caucasianos.

\section{PALAVRAS-CHAVE}

Comparação cefalométrica; Características esqueléticas e dentárias; Normas iemenitas. 


\section{INTRODUCTION}

C ephalometric radiograph has been used to analyze the morphology of the major structures of the head in the vertical and sagittal dimensions [1]. The norms of cephalometric measurements have been utilized to detect the severe discrepancies in dentofacial structures and to assess the variations that join treatment in orthodontics $[2,3]$.

The cephalometric norms have been determined for different nations and populations almost all over the world and for various ethnic groups [4-16]. All these studies show that the normal measurements for one group should not be judged as a normal for every other race or ethnic group. Thus, it is necessary to assess a patient's cephalometric measurements per the standards for his racial group and treat them according to their special norms.

Recently, Yemeni cephalometric norms have been developed and are still few in literature. One of the two published studies for Yemenis was performed by Al-Gunaid [17], who developed cephalometric norms of soft tissue for Yemeni men. His study included only males and was limited to the soft tissue. The other was conducted by Daer [18], who established cephalometric norms of skeletal and dental tissues for Yemenis according to Harvold's cephalometric analysis without soft tissue analysis.

From the abovementioned review, published researches that have developed cephalometric norms for Yemenis are few and inadequate. For example, the dimensions from the incisors and molars to the palatal and the mandibular planes for Yemenis have not determined. These linear measurements are helpful to assess whether anterior dental open bite is caused by the deficiency in the eruption of the incisors or the excess of eruption of the molars [19]. So, these measurements may assist in verifying if the open bite is correlated more to the anterior or posterior measurements. Therefore, the objectives of our study were (1) to develop skeletal, dental, and soft tissue cephalometric standards for Yemeni adults; and (2) to compare Yemeni norms with those of the Caucasians to determine whether significant racial differences exist between them.

\section{MATERIAL AND METHODS}

This research was conducted in the Faculty of Dentistry, Sana'a University. One thousand, two hundred and nine Yemeni dental students were examined in the orthodontic clinics of the Faculty. The interviews and clinical examinations were performed by one operator. One hundred and twelve students have fulfilled the criteria of selection, which were: Yemeni with Yemeni grandparents, skeletal and dental class I, normal occlusion with minor or no crowding, normal overbite and overjet, the whole teeth is present except third molars and no history of orthodontic treatment. Five females refused to contribute to the study and were excluded.

Ethical approval was obtained from the Ethical Committee of the Medical Research in the University and a consent was obtained from the contributors after explaining the character and objective of the radiographs. Subjects who met the selection criteria and signed a consent form were taken to the radiology department. Each selected subject was positioned in a system unit (PaX-Flex3D P2, Ver. 1.0.0, Vatech, Korea) of a private radiology center (Al Waleed 3D Digital X-Ray, Sana'a), and a cephalometric radiograph was taken at $85 \mathrm{kV}$ and $10 \mathrm{~mA}$ per second.

Lateral cephalograms of one hundred and seven Yemeni adults were taken. However, only one hundred images (50 male, mean age of 23.6 \pm 2.1 years -50 females, mean age of $21.5 \pm$ 3.1 years) were considered to be acceptable by 2 orthodontist evaluators. The remaining seven radiographs were excluded due to the poor quality of the images. Each participant's head was stabilized by a head holder and placed in front of a mirror to ensure that the head was directed in natural head position - the true vertical perpendicular to the floor and the true horizontal parallel to the floor [20]. Participants were asked to close their teeth on centric occlusion with lips in repose. 


\section{Sample size}

The sample size was calculated using nMaster software, Version 1.0 (Department of Biostatistics, Christian Medical College, Vellore, India). The calculated minimum sample size was 40 subjects of each gender. But, in order to enhance the statistical power of the results, we increased the sample size to a total of 100 subjects.

\section{Landmarks Used in the Study}

Landmarks used in the study (Figure 1) were:

Nasion (N), Basion (Ba), Orbital (Or), Porion (Po), Pogonion (Pog), Gnathion (Gn), Menton (Me), Gonion (Go), point A (A), Condylion (Co), Anterior nasal spine (ANS), Posterior nasal spine (PNS), the pterygomaxillary fissure (PTM), Incision superius (Is), Incision inferius (Ii), Subnasale (Sn), Labrale Superius (Ls), Labrale inferius (Li) and Soft tissue Pogonion ( Pog'). The definitions of these different landmarks have been stated before by Riolo et al [21].

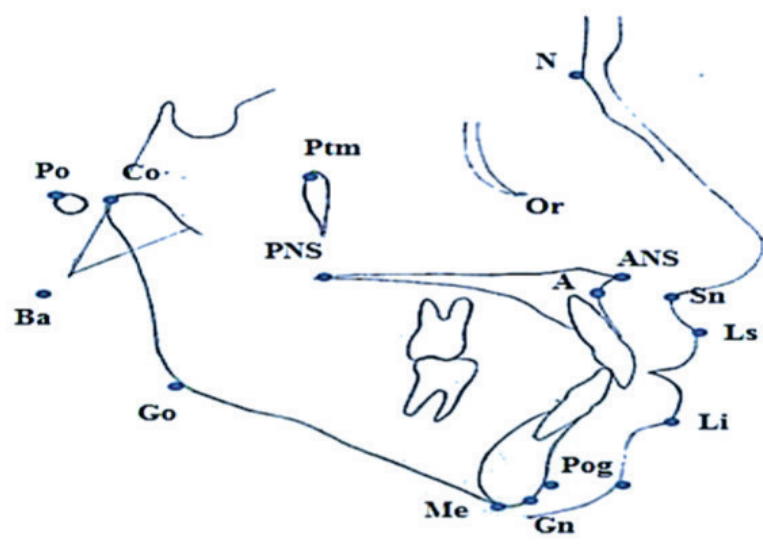

Figure 1- Cephalometric reference points used in the study.

\section{Reliability of Landmark Localization}

Cephalometric radiographs of all participants were traced using $0.003-\mathrm{mm}$ matte acetate papers and measured by hand. All the tracings and measurements were done by one investigator (the first author, A.A) at the Orthodontic department, Faculty of Dentistry. Landmarks were checked for accuracy of points' identification by the supervisor. The middle point of the bilateral landmarks was used. Evaluation of errors in landmarks localization during tracing was done by having the same investigator retrace all radiographs.

\section{Cephalometric Measurements}

From previously described landmarks, five angular and eighteen linear measurements were determined to evaluate the skeletal, dental and soft tissue relationships, Figures 2-4.

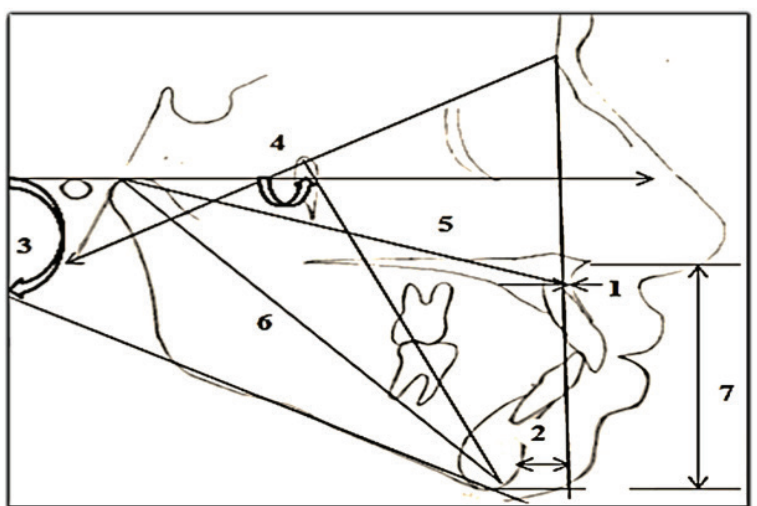

Figure 2 - Skeletal angular and linear measurements: 1. Nasion perpendicular to point $A$, the dimension from point $A$ to nasion perpendicular line ( $\mathrm{mm})$, 2. Pog to nasion perpendicular, the dimension from pogonion to the nasion perpendicular line $(\mathrm{mm}), 3$. Frankfort to mandibular plane angle, the angle between the Frankfort plane and the mandibular plane, 4. Facial axis angle, the angle formed by the basionnasion plane and the plane from foramen rotundum to Gnathion, 5. Effective midfacial length, dimension from condylion to point $A(\mathrm{~mm})$ 6. Effective mandibular length, dimension from condylion to Gnathion $(\mathrm{mm}), 7$. Lower face height, dimension from ANS to menton.

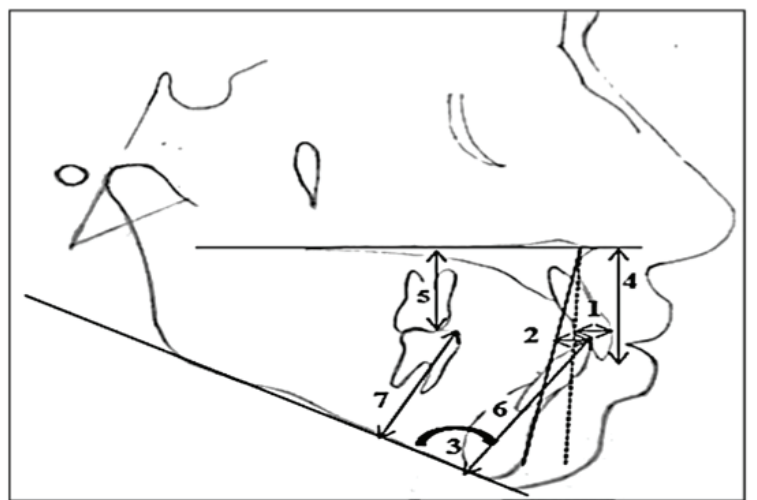

Figure 3 - Dental angular and linear measurements: 1. Upper incisor to point $A$, the dimension from labial surface of the upper incisor to point A (mm), 2. Lower incisor to A-Pog line, ), the dimension from the edge of the lower incisor to a line from point $A$ to pogonion $(\mathrm{mm}), 3$. Lower incisor to mandibular plane angle, the angle formed between the long axis of the lower incisor and the mandibular plane, 4. Upper incisor to palatal plane, the dimension from the edge of the upper incisor to the palatal plane $(\mathrm{mm}), 5$. Upper molar to palatal plane, the dimension from the mesial cusp of the upper first molar to the palatal plane $(\mathrm{mm}), 6$. Lower incisor to mandibular plane, the dimension from the edge of the lower incisor to the mandibular plane, 7. Lower molar to mandibular plane, the dimension from the mesial cusp of the lower first molar to the mandibular plane $(\mathrm{mm})$ 


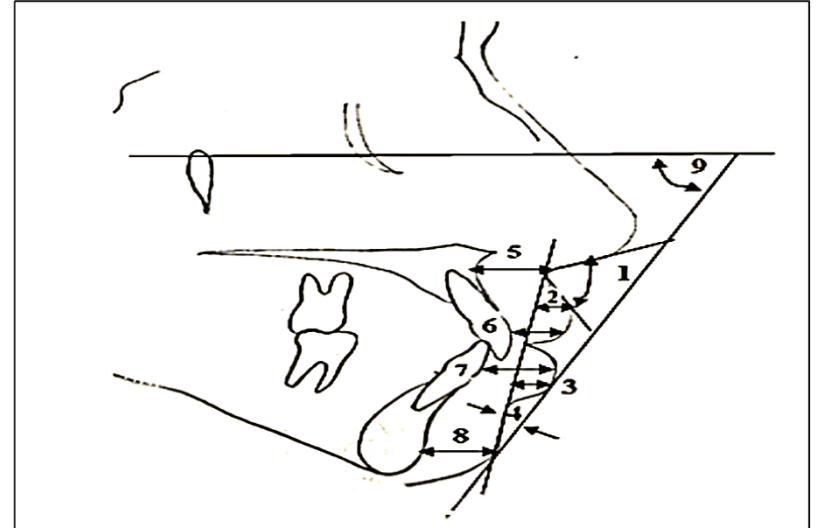

Figure 4 - Soft tissue angular and linear measurements: 1.Nasolabial angle, the angle formed between a line tangent to the base of the nose and a line tangent to the upper lip, 2. Upper lip protrusion, the dimension from labrale superius to a line( from subnasale to soft tissue pogonion) (mm), 3. Lower lip protrusion, the dimension from labrale inferius to a line( from subnasale to soft tissue pogonion) (mm), 4. Mentolabial sulcus, the maximum depth from a line connecting soft tissue pogonion and the lower lip (mm), 5. Point A to Subnasale, the dimension from point A to Subnasale $(\mathrm{mm}), 6$. Incision superioris to upper lip, the dimension from incision superioris to the upper lip $(\mathrm{mm}), 7$. Incision inferioris to lower lip, the dimension from incision inferioris to the lower lip $(\mathrm{mm}), 8$. Pogonion to pogonion', the dimension from hard tissue Pogonion to soft tissue pogonion $(\mathrm{mm})$, 9. Z angle, the angle formed by the intersection of Frankfort plane and a line connecting soft tissue pogonion and the most protrusive lip point.

\section{Statistical Analysis}

The basic statistics, including the mean, standard deviation, minimum and maximum values for all the variables were calculated for each gender. Unpaired t-tests were used to detect if there are any differences in cephalometric standards between Yemenis and Caucasians. The norms of Caucasian adults were derived from a study conducted by Ioi [19].

All these statistical analysis were performed using the Statistical Package for Social Sciences SPSS software (IBM SPSS Statistics, V 22.0, Chicago, United States). The $\mathrm{P}$ value of $\mathrm{P}<0.05$ was predetermined as statistically significant. Twenty radiographs were selected randomly from all radiographs that have been retraced by the same investigator after two weeks from the first measurements. Errors in cephalometric tracing were evaluated using Dahlberg's formula [22]. The errors were from $0.04^{\circ}$ to $0.28^{\circ}$ for the angular measurements and from 0.02 to 0.36 $\mathrm{mm}$ for the linear measurements (Table I).
Table I - Methodological cephalometric tracing errors

\begin{tabular}{|c|c|}
\hline Measurement & Dahlberg's value \\
\hline Point A-N perpendicular (mm) & .026 \\
\hline Pog - N perpendicular (mm) & .144 \\
\hline F.MPA $\left({ }^{\circ}\right)$ & .046 \\
\hline F.A.A $\left(^{\circ}\right)$ & .210 \\
\hline M.F.L (mm) & .364 \\
\hline Mand.L (mm) & .113 \\
\hline L.F.H (mm) & .150 \\
\hline Ui-point $A(m m)$ & .179 \\
\hline Li-A-Pog (mm) & .079 \\
\hline Li-M.P.A $\left({ }^{\circ}\right)$ & .258 \\
\hline $\mathrm{Ui}-\mathrm{Pp}(\mathrm{mm})$ & .254 \\
\hline Um-Pp (mm) & .116 \\
\hline $\mathrm{Li}-\mathrm{Mp}(\mathrm{mm})$ & .104 \\
\hline Lm- Mp (mm) & .138 \\
\hline Nasolabial angle $\left(^{\circ}\right)$ & .288 \\
\hline Ls to Sn-Pog'(mm) & .137 \\
\hline Li to Sn-Pog'(mm) & .070 \\
\hline M.L.S (mm) & .135 \\
\hline Point A-Sn (mm) & .084 \\
\hline IS-Ulip (mm) & .110 \\
\hline li-L lip (mm) & .053 \\
\hline Pog-Pog' (mm) & .099 \\
\hline Zangle $\left(^{\circ}\right)$ & .103 \\
\hline
\end{tabular}

\section{RESULTS}

The basic statistics of the cephalometric variables for the Yemeni males and females are shown in Table II. The comparisons between Yemenis and Caucasians are shown in Tables III and IV.

\section{Comparisons between Yemeni Males and Females}

\section{(Table II)}

Table II shows the comparisons between the Yemeni males and females and revealed that the Yemeni males are significantly $(\mathrm{P}<0.001)$ greater than the females in three linear skeletal measurements, E.M.L, E.Man.L and L.F.H; in one dental angle parameter, Li- $\mathrm{MPA}^{\circ}(\mathrm{P}<$ 0.01); and four linear dental measurements, Ui-Pp, Um-Pp, Li-Mp and Lm-Mp $(\mathrm{P}<0.001)$ and in all soft tissue linear measurements: Ls to Sn-Pog ' $(\mathrm{P}<0.001)$, Li to Sn-Pog ' $(\mathrm{P}<0.05)$, M.L.S, point A-Sn, Is-U Lip, Ii- L Lip $(\mathrm{P}<0.001)$ and Pog- Pog' $(\mathrm{P}<0.01)$. 
Table II - The comparisons between Yemeni males and females

\begin{tabular}{|c|c|c|c|c|c|}
\hline \multirow{2}{*}{ Variables } & \multicolumn{2}{|c|}{ Yemenimales } & \multicolumn{2}{|c|}{ Yemeni females } & \multirow{2}{*}{ Significance } \\
\hline & Mean & SD & Mean & SD & \\
\hline \multicolumn{6}{|l|}{ Skeletal relationship } \\
\hline Point A-N perpendicular (mm) & 2.1 & 1.9 & 1.9 & 1.5 & NS \\
\hline Pog - N perpendicular (mm) & -5.0 & 4.1 & -3.7 & 3.4 & NS \\
\hline $\operatorname{F.MPA}\left({ }^{\circ}\right)$ & 27.3 & 4.4 & 27.7 & 4.3 & NS \\
\hline F.A.A $\left(^{\circ}\right)$ & 89.2 & 3.8 & 88.8 & 3.8 & NS \\
\hline M.F.L (mm) & 103.9 & 7.4 & 96.7 & 7.6 & *** \\
\hline Mand.L (mm) & 135.2 & 9.0 & 124.8 & 9.7 & $* * *$ \\
\hline L.F.H (mm) & 76.9 & 5.9 & 70.5 & 5.8 & $* \star \star$ \\
\hline \multicolumn{6}{|l|}{ Dental relationship } \\
\hline Ui-point A (mm) & 6.5 & 6.3 & 6.1 & 1.8 & NS \\
\hline Li-A-Pog (mm) & 4.4 & 2.1 & 4.0 & 2.2 & NS \\
\hline Li-M.P.A $\left({ }^{\circ}\right)$ & 96.4 & 6.6 & 93.1 & 5.0 & ** \\
\hline $\mathrm{Ui}-\mathrm{Pp}(\mathrm{mm})$ & 32.8 & 3.6 & 31.0 & 3.5 & * \\
\hline Um-Pp (mm) & 28.3 & 3.0 & 25.9 & 2.7 & $\star \star \star ~$ \\
\hline $\mathrm{Li}-\mathrm{Mp}(\mathrm{mm})$ & 49.4 & 3.9 & 44.2 & 4.1 & $* \star *$ \\
\hline $\mathrm{Lm}-\mathrm{Mp}(\mathrm{mm})$ & 37.4 & 3.8 & 33.4 & 3.9 & 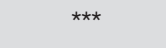 \\
\hline \multicolumn{6}{|l|}{ Soft tissue relationship } \\
\hline Nasolabial angle $\left({ }^{\circ}\right)$ & 104.5 & 7.2 & 103.6 & 8.2 & NS \\
\hline Ls to Sn-Pog' $(\mathrm{mm})$ & 5.3 & 2.2 & 3.6 & 1.6 & 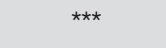 \\
\hline Li to Sn-Pog'(mm) & 4.2 & 2.0 & 3.3 & 1.9 & * \\
\hline M.L.S (mm) & 6.0 & 1.4 & 5.0 & 1.4 & 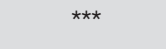 \\
\hline Point A-Sn (mm) & 18.4 & 2.8 & 16.0 & 2.1 & 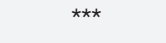 \\
\hline IS-U lip (mm) & 12.7 & 2.6 & 9.9 & 2.0 & $* * *$ \\
\hline li-L lip (mm) & 15.0 & 2.4 & 12.6 & 2.3 & 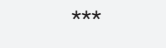 \\
\hline Pog-Pog' (mm) & 13.1 & 2.8 & 11.6 & 2.4 & ** \\
\hline Zangle $\left(^{\circ}\right)$ & 75.3 & 7.4 & 72.8 & 6.9 & NS \\
\hline
\end{tabular}

${ }^{\star} \mathrm{P}=0.05,{ }^{\star \star} \mathrm{P}=0.01,{ }^{\star \star \star} \mathrm{P}=0.001, \mathrm{NS}$ : not significant 


\section{Comparisons between Yemeni and Caucasian Males (Table III)}

Table III - Comparison of sample means between Yemeni and Caucasian males

\begin{tabular}{|c|c|c|c|c|c|}
\hline \multirow{2}{*}{ Variables } & \multicolumn{2}{|c|}{ Yemeni males } & \multicolumn{2}{|c|}{ Caucasian females } & \multirow{2}{*}{ Significance } \\
\hline & Mean & SD & Mean & SD & \\
\hline \multicolumn{6}{|l|}{ Skeletal relationship } \\
\hline Point A-N perpendicular (mm) & 2.1 & 1.9 & 1.1 & 2.7 & NS \\
\hline Pog - N perpendicular (mm) & -5.0 & 4.1 & -0.3 & 3.8 & * \\
\hline F.MPA $\left({ }^{\circ}\right)$ & 27.3 & 4.4 & 21.3 & 3.9 & ** \\
\hline F.A.A $\left(^{\circ}\right)$ & 89.2 & 3.8 & 90.5 & 3.5 & NS \\
\hline M.F.L (mm) & 103.9 & 7.4 & 99.8 & 6.0 & * \\
\hline Mand.L (mm) & 135.2 & 9.0 & 134.3 & 6.8 & NS \\
\hline L.F.H (mm) & 76.9 & 5.9 & 74.6 & 5.0 & NS \\
\hline \multicolumn{6}{|l|}{ Dental relationship } \\
\hline Ui-point A (mm) & 6.5 & 6.3 & 5.3 & 2.0 & NS \\
\hline Li-A-Pog (mm) & 4.4 & 2.1 & 2.3 & 2.1 & * \\
\hline Li-M.P.A $\left({ }^{\circ}\right)$ & 96.4 & 6.6 & 92.3 & 7.4 & $\star \star$ \\
\hline $\mathrm{Ui}-\mathrm{Pp}(\mathrm{mm})$ & 32.8 & 3.6 & 33.0 & 3.2 & NS \\
\hline $\mathrm{Um}-\mathrm{Pp}(\mathrm{mm})$ & 28.3 & 3.0 & 27.9 & 3.1 & NS \\
\hline $\mathrm{Li}-\mathrm{Mp}(\mathrm{mm})$ & 49.4 & 3.9 & 44.2 & 3.0 & NS \\
\hline Lm-Mp (mm) & 37.4 & 3.8 & 38.0 & 2.8 & NS \\
\hline \multicolumn{6}{|l|}{ Soft tissue relationship } \\
\hline Nasolabial angle $\left({ }^{\circ}\right)$ & 104.5 & 7.2 & 102.0 & 8.0 & NS \\
\hline Ls to Sn-Pog' (mm) & 5.3 & 2.2 & 3.0 & 1.0 & ** \\
\hline Li to Sn-Pog' (mm) & 4.2 & 2.0 & 2.0 & 1.0 & $\star \star$ \\
\hline M.L.S (mm) & 6.0 & 1.4 & 4.0 & 2.0 & $\star \star$ \\
\hline Point A-Sn (mm) & 18.4 & 2.8 & 19.7 & 1.4 & NS \\
\hline IS-Ulip (mm) & 12.7 & 2.6 & 13.7 & 2.2 & NS \\
\hline li-L lip (mm) & 15.0 & 2.4 & 15.5 & 1.9 & NS \\
\hline Pog-Pog' (mm) & 13.1 & 2.8 & 13.3 & 1.7 & NS \\
\hline Zangle $\left(^{\circ}\right)$ & 75.3 & 7.4 & 75.5 & 8.3 & NS \\
\hline
\end{tabular}

The skeletal, dental and soft tissue norms of Caucasians were derived from loi et al. (2007) [19].

${ }^{\star} \mathrm{P}=0.05,{ }^{\star \star} \mathrm{P}=0.01,{ }^{\star \star \star} \mathrm{P}=0.001$, NS: not significant 
Skeletal angular and linear measurements: The Pog-N perpendicular measurement, Frankfort to mandibular plane angle and effective midfacial length were significantly $(\mathrm{P}<0.05)$ larger in Yemenis compared with that of Caucasians.

Dental angular and linear measurements: The Li- A-Pog measurement in Yemeni males was greater than that of the Caucasians $(\mathrm{P}<0.05)$, and the Li-MP angle (the long access of the lower incisor with the mandibular plane) was larger in Yemeni males $(P<0.01)$. There were no significant differences $(P>0.05)$ in other dental measurements between Yemeni and Caucasian males.

Soft tissue measurements: Ls to SnPog', Li to Sn-Pog' and the mentolabial sulcus measurements in Yemeni males were significantly $(\mathrm{P}<0.01)$ larger compared with the Caucasians.

\section{Comparisons between Yemeni and} Caucasian Females (Table IV)

Skeletal angular and linear measurements: all these measurements were significantly different between Yemeni and Caucasian females, Frankfort to mandibular plane angle and lower facial height were significantly $(\mathrm{P}<0.001)$ greater in Yemeni females,. Also, the Pog to nasion perpendicular and effective mandibular length was larger $(\mathrm{P}<0.01)$ compared with that of Caucasian females. Point A to nasion perpendicular and effective midfacial length was greater $(\mathrm{P}<0.05)$ in Yemeni females. However, facial axis angle was smaller in Yemeni females than that of Caucasians $(\mathrm{P}<0.01)$.

Dental angular and linear measurements: The Ui- point $\mathrm{A}(\mathrm{P}<0.05)$ and Li- A-Pog measurements $(\mathrm{P}<0.01)$ in Yemeni females were greater than that of the Caucasians. There were no significant differences in other dental measurements between Yemeni and Caucasian females.

Soft tissue measurements: Li to Sn-Pog' and mentolabial sulcus in Yemeni females were significantly $(\mathrm{P}<0.05)$ larger compared with Caucasians.
Table IV - Comparisons of sample means between Yemeni and Caucasian females

\begin{tabular}{|c|c|c|c|c|c|}
\hline \multirow{2}{*}{ Variables } & \multicolumn{2}{|c|}{ Yemenimales } & \multicolumn{2}{|c|}{$\begin{array}{l}\text { Caucasian } \\
\text { females }\end{array}$} & \multirow{2}{*}{$\begin{array}{l}\text { Signifi- } \\
\text { cance }\end{array}$} \\
\hline & Mean & SD & Mean & SD & \\
\hline \multicolumn{6}{|l|}{ Skeletal relationship } \\
\hline PointA-N perpendicular (mm) & 1.9 & 1.5 & 0.4 & 2.3 & * \\
\hline Pog - N perpendicular (mm) & -3.7 & 3.4 & -1.8 & 4.5 & ** \\
\hline F.MPA $\left({ }^{\circ}\right)$ & 27.7 & 4.3 & 22.7 & 4.3 & 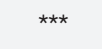 \\
\hline F.A.A $\left(^{\circ}\right)$ & 88.8 & 3.8 & 90.2 & 3.2 & ** \\
\hline M.F.L (mm) & 96.7 & 7.6 & 91.0 & 4.3 & * \\
\hline Mand.L (mm) & 124.8 & 9.7 & 120.2 & 5.3 & ** \\
\hline L.F.H (mm) & 70.5 & 5.8 & 66.7 & 4.1 & *** \\
\hline \multicolumn{6}{|l|}{ Dental relationship } \\
\hline Ui-point A (mm) & 6.1 & 1.8 & 5.4 & 1.7 & * \\
\hline Li-A-Pog (mm) & 4.0 & 2.2 & 2.7 & 1.7 & ** \\
\hline Li-M.P.A $\left(^{\circ}\right)$ & 93.1 & 5.0 & 94.9 & 6.3 & NS \\
\hline $\mathrm{Ui}-\mathrm{Pp}(\mathrm{mm})$ & 31.0 & 3.5 & 30.0 & 2.9 & NS \\
\hline Um- Pp (mm) & 25.9 & 2.7 & 24.8 & 2.2 & NS \\
\hline $\mathrm{Li}-\mathrm{Mp}(\mathrm{mm})$ & 44.2 & 4.1 & 41.5 & 3.1 & NS \\
\hline $\mathrm{Lm}-\mathrm{Mp}(\mathrm{mm})$ & 33.4 & 3.9 & 32.6 & 2.9 & NS \\
\hline \multicolumn{6}{|l|}{ Soft tissue relationship } \\
\hline Nasolabial angle $\left(^{\circ}\right)$ & 103.6 & 8.2 & 102.0 & 8.0 & NS \\
\hline Ls to Sn-Pog'(mm) & 3.6 & 1.6 & 3.0 & 1.0 & NS \\
\hline Li to Sn-Pog'(mm) & 3.3 & 1.9 & 2.0 & 1.0 & * \\
\hline M.L.S (mm) & 5.0 & 1.4 & 4.0 & 2.0 & * \\
\hline Point A-Sn (mm) & 16.0 & 2.1 & 15.3 & 1.6 & NS \\
\hline IS-U lip (mm) & 9.9 & 2.0 & 10.9 & 1.6 & NS \\
\hline li-L lip (mm) & 12.6 & 2.3 & 12.9 & 1.8 & NS \\
\hline Pog-Pog' (mm) & 11.6 & 2.4 & 11.1 & 1.8 & NS \\
\hline Zangle $\left(^{\circ}\right)$ & 72.8 & 6.9 & 71.3 & 7.7 & NS \\
\hline
\end{tabular}

The skeletal, dental and soft tissue norms of Caucasians were derived from loi et al (2007) [19].

${ }^{*} P=0.05$

** $P=0.01$

*** $P=0.001$

NS, not significant

\section{DISCUSSION}

It was necessary to identify what is considered natural and pleasing for Yemenis because of the increasing numbers of Yemenis looking for specialized treatment by orthodontists, cosmetic surgeons, and maxillofacial surgeons. The objectives of this study were to create norms of Yemeni adults for orthodontists to diagnose 
and treat Yemeni patients according to their special standards and to compare them with the Caucasian norms. This study is the first to compare the Yemeni dentofacial parameters with the Caucasians.

Our research conducted on a group of Yemeni adult subjects who had a skeletal and dental class I relationships and had not received any orthodontic treatment before. The subjects were grouped per gender to achieve more precise and specific cephalometric standards. The sample was selected from the biggest university in the Capital city, which involved students from several areas of the country.

\section{Skeletal Relationship}

The bimaxillary growth determined by the maxillary and mandibular positions in our studied sample showed significant differences per the gender.

The maxilla in the sagittal plane was slightly more protrusive in males, while the chin was more retruded in them (Pog-Nv. mm). Therefore, considering skeletal facial convexity, the profiles were more convex in Yemeni males more than females due to retrognathic mandible rather than prognathic maxilla. Maxillary and mandibular sagittal lengths were longer in the Yemeni males than the females. This difference in size of jaws in males corresponds with their larger skeletal structure of skull.

Comparing with the Caucasians, the position of the maxilla relative to the anterior cranial base in Yemeni males was nearly the same as that of the Caucasians, while in the Yemeni females the maxilla was more protrusive. On the other hand, the position of the mandible for the Yemenis was more retrusive in both gender compared with the Caucasians. These mean that the Yemenis had a more convex profile and more retruded mandible than the Caucasians and these findings were similar to Al-Gunaid study [17], who concluded that Yemenis had a more convex profile and more retruded mandible than the North American white people. Our result was different from those of AlJasser [14], who found that Saudi Arabians have facial convexity and mandibular prognathism, representing that Yemenis also had more convex profile than Saudi adults, despite they live near together and could be from similar ethnic group.

In the vertical dimension, the Frankfort to mandibular plane angle, the effective mandibular length and the lower anterior facial height in Yemenis were larger than those of the Caucasian sample. These findings mean that the Yemenis with natural occlusions are dolichofacial more than brachyfacial; whereas, Caucasians are more brachyfacial [23]. The backward mandibular growth rotation suggested by the increase in Frankfort mandibular plane angle (steeper mandibular plane angle) and the retrusive chin position, may explain the increased vertical dimension in Yemenis.

\section{Dental Relationship}

The lower incisors positions in Yemeni adults were more protruded and tilted labially than those in the Caucasians, which might be a compensation for the retrusive mandible in Yemenis. This result is nearly similar to the value attained by Hassan for Saudi adults [15].

In the vertical dimension, the lower incisor and lower molar to the mandibular plane, the upper incisor and upper molar to palatal plane, in Yemeni samples, showed no statistical differences compared to those of the Caucasian samples, but there were a statistical differences in those measurements between Yemeni males and females (those values were all larger in males), these values of the dental vertical lengths may be helpful to verify which teeth participate more to the vertical disharmonies of open or deep bites.

\section{Soft Tissue Analysis}

There was no significant difference in the nasolabial angle between Yemenis and Caucasians. But this angle was larger than that found in Saudi adults by Al-Jasser [14], which mean that Yemenis have more obtuse nasolabial angle than Saudis.

Regarding the lip appearance, upper and lower lips were more protrusive in Yemeni males than females. This could be due to the more protruded lower incisors in males rather than the actual prominence of the lip. When this 
compared with the Caucasians, Yemeni males had a significantly more protruded upper and lower lip positions, while Yemeni females had a significantly more protrusion just in lower lip positions. The mentolabial sulcus in Yemenis subjects was significantly deeper than that in Caucasians. This result is close to Al-Gunaid for Yemeni subjects [17]. In spite of the retruded bony chin of Yemeni males, their soft tissue chin was thicker than females, which may have played a role in masking partially the retrusion in their bony chin.

Yemenis have different cephalometric features and profile, not just from the Caucasians, but also from Saudi adults, which live near to them and may have similar ethnic background. Thus, these Yemeni specific cephalometric values may be helpful in diagnosing and achieving more pleasing results in the treatment of Yemeni patients. However, additional studies are needed among different age groups using different cephalometric analysis to evaluate overall views of the normal occlusion for Yemeni population.

\section{CONCLUSION}

1. Cephalometric norms of the Yemenis were different from those of the Caucasians in several aspects: mandibular position relative to nasion perpendicular line, mandibular plane angle, medfacial length, lower facial height, position of incisors, lip position, profile and labiomental sulcus.

2. Yemenis showed more convex profiles because of their more retruded mandibles, protruded lower incisors and lips. They were more dolichofacial than Caucasians considering the longer facial heights and steeper mandibular plane angles.

3. This cephalometric values for Yemeni adults will assist in the diagnosis and treatment planning for orthodontic Yemeni patients.

4. The cephalometric standards shows the averages of the populations, so it is essential also to consider every patient's desires and needs during the diagnosis and treatment planning instead of taking these norms as a template.

\section{REFERENCES}

1. Proffit WR, Fields Jr, HW, Sarver DM. Contemporary orthodontics. Amsterdan: Elsevier;2007.

2. KoskiK. The norm concept in dental orthopedics. Angle Orthod. 1955;25:113-7.

3. Bishara SE, Abdalla EM, Hoppens BJ. Cephalometric comparisons of dentofacial parameters between Egyptian and North American adolescents. Am J Orthod Dentofacial Orthop.1990;97:413-21.

4. Anderson AA, Anderson AC, Hornbuckle AC, Hornbucklez K. Biological derivation of a range of cephalometric norms for children of African American descent (after Steiner). Am J Orthod Dentofacial Orthop. 2000;118:90-100.

5. Swlerenga D, Oesterle LJ, Messersmith ML. Cephalometric values for adult Mexican-American. Am J Orthod Dentofacial Orthop.1994;106:146-55.

6. Axelsson S, Kjær I, Bjørnland T, Storhaug K. Longitudinal cephalometric standards for the neurocranium in Norwegians from 6 to 21 years of age. Eur J Orthod. 2003;25:185-98.

7. Canut J, Miñana PM, Plasencia E. Facial differences between northern and southern European children. Angle orthod. 1987;57:63-9.

8. Cerci V,Martins JE, de Oliveira MA. Cephalometric standards for white Brazilians. Int J Adult Orthod Orthognath Surg.1993;8(4):287-92.

9. Hajighadimi M, Dougherty HL, Garakani F. Cephalometric evaluation of Iranian children and its comparison with Tweed's and Steiner's standards. Am J Orthod Dentofacial Orthop. 1981;79:192-7.

10. Drummond RA. A determination of cephalometric norms for the Negro race. Am J Orthod Dentofacial Orthop. 1968;54:670-82.

11. Engel G, Spolter BM. Cephalometric and visual norms for a Japanese population. Am J Orthod Dentofacial Orthop.1981;80:48-60.

12. Abu-Tayyem HM, Alshamsi AH, Hafez S, EIDin EM. Cephalometric norms for a sample of Emirates adults. Open J of Stomatol. 2011;1:75-83

13. Ayhan BF, Uysal T, Buyukerkmen A. Craniofacial structure of Anatolian Turkish adults with normal occlusions and well-balanced faces. Am J Orthod Dentofacial Orthop. 2004;125(3):366-72.

14. Al-Jasser NM. Cephalometric evaluation for Saudi population using the Downs and Steiner analysis. J Contemp Dent Pract. 2005;6:52-63.

15. Hassan AH. Cephalometric norms for Saudi adults living in the western region of Saudi Arabia. Angle Orthod. 2006;76:109-13.

16. Al-Jame B, Artun J, Al-Azemi R, Behbehani F, Buhamra S. Lateral cephalometric norms for adolescent Kuwaitis: hard tissue measurements. Med Princ Pract. 2006;15:91-7.

17. Al-Gunaid T, Yamada K, Yamaki M, Saito I. Soft-tissue cephalometric norms in Yemeni men. Am J Orthod Dentofacial Orthop. 2007;132: 576. e7-576. e14.

18. Daer AA, AbuAffan AH. Cephalometric Features of Yemeni Adults Norms. Int JRecent Sci Res. 2015;6(9):6264-9.

19. Ioi H, Nakata S, Nakasima A, Counts AL. Comparison of cephalometric norms between Japanese and Caucasian adults in antero-posterior and vertical dimension. Eur J Orthod. 2007;29:493-9.

20. Peng L, Cooke MS. Fifteen-year reproducibility of natural head posture: a longitudinal study. Am J Orthod Dentofacial Orthop. 1999;116:82-5.

21. Riolo ML, Moyers RE, McNamara JA Jr, Hunter WS. An atlas of craniofacial growth. Monograph No. 2, Craniofacial Growth Series. Ann Arbor, Mich: Center for Human Growth and Development, University of Michigan;1974:261-70. 
22. Dahlberg G. Statistical methods for medical and biological students. New York:Interscience; 1940.
23. Christie TE. Cephalometric patterns of adults with normal occlusion. Angle Orthod. 1977;47:128-35.

\section{Amal Al-Yousefi}

(Corresponding address)

MD in Clinical Orthodontics, Division of Orthodontics, Department of Orthodontics, Pedo-

dontics and Prevention, Faculty of Dentistry, Sana'a University, Sana'a, Yemen.

Email: dramal2010.as@gmail.com

Date submitted: 2020 Aug 20

Accept submission: 2020 Sep 29 